\title{
Jacopo Tomatis: Storia culturale della canzone italiana. Milan: Il Saggiatore, 2019. ISBN 978-8842825463. 816 pages.
}

Many years ago, when poet, lyricist, and singer Umberto Fiori reviewed my early book on music and young audiences (Musica e pubblico giovanile, Feltrinelli, 1980; Odoya, 2014²), he pointed out that my sociological analysis demonstrated, among other things, that a history of popular music could not be written; trying to write a history of popular music was akin to writing the biography of a Disney character.

Fast-forward to the present. Do all the histories of Italian song and Italian popular music that are now in print contradict Fiori's statement? Yes and no, because the problem with writing a history of popular music (historiography is a peculiar Italian obsession; no other country has produced so many histories of national literature) is that popular music is, by and large, a horizontal landscape. There are peaks and valleys, but the greatest pop song is always mirrored in the worst pop song and the opposite is also true. Songs that were ignored upon their release may resurface and become canonical overnight (all it takes is a good cover, as it happened to Leonard Cohen's "Halleluiah"). The process is much faster and unpredictable than whatever may occur in other departments (literature, film, the arts, etc.).

Italy has always been bent on strong canons, and the canon of Italian popular music is indeed as strong as the literary one. No one can dispute the cultural pre-eminence of the cantautori (singer-songwriters) from the second half of the 1950s to the 1990s, regardless of the many other styles and genres that thrived in the same years. The emergence of the new Italian song, starting with Domenico Modugno in the mid-1950s, was immediately accompanied by a large amount of social conversation. The intellectuals were slow to catch on, but ultimately, they did, and the cultural/political 'debate about music' (dibattito sulla musica) never stopped until the mid-1980s. Jacopo Tomatis, who teaches popular music at the University of Turin, was therefore able to put together an impressive volume of more than 800 pages on the cultural history of Italian song; not a complete history (we would need to go back to the fourteenth century for that), but a narrative that starts in the nineteenth century, when songs became closer to what we call popular music today, and then moves quickly to the 1950 s and beyond, with a short final section that summarizes what happened after the 1980s.

After a short but poignant introduction on the anthropological traits of the Italian song, Tomatis leaves no stone unturned when it comes to dissecting the diverging positions taken by the Italian intellectuals - mostly on the left - on the political validity and use of this medium which was at the same time very old and very new. The story has been told many times (I was one of the first who tried to tell it), but no one matches the accuracy of Tomatis' 
research, disseminated over thousands of quotes, notes, and a very extensive bibliography.

Personally, I must add the flavor of a time gone by - a time that Tomatis himself is too young to remember, yet it comes alive in his book in all its shattered glory. Today, a young reader might wonder why a minimal difference in lyrics, musical arrangement or choice of a venue for a music event would generate such an amount of vitriolic accusations, political turmoil, mob riots and violence, as if pop musicians, pop critics, pop promoters and the audience were fighting for Kingdom Come on the lawn of a stadium where an innocuous rock concert was about to take place. Indeed, they were, and that is very difficult to explain today. Read Tomatis if you were not there, and good luck. Back then, I was a songwriter, the press agent of an independent label (Milan-based L'Orchestra), and a music critic. The horror and the adrenaline of all those overheated exchanges are still in my mind, and I am amazed at how Tomatis has been able to recreate that little lost world, which was not so little after all, when music had turned into a weapon of extreme class struggle.

The question concerning the possibility to write a history of popular music entirely related to a time-period that you have not lived through is not a foolish one. Popular music is different in its reception from other forms of art. It goes deep under the skin; sentimentality, nostalgia, and what Simon Reynolds has called retromania make it hard to write an objective account of it. The historian of popular music does not enjoy the same critical distance that other scholars have at their disposal. Today, the sorrows of the world seem to have found their place in the comment section of YouTube, and even more so in the Italian comments. All it takes is the initial chord of a Lucio Battisti song to make grown-up people cry like newborn calves that have lost their mother and write passionate posthumous love letters to their teenage crush who is probably a grandmother now.

The social conversation about music that took place in Italy in those lost decades is a historical phenomenon possibly matched only by the birth of rock criticism in the U.S. and the discussion about the authenticity of folk music in Great Britain. It will never happen again, and it is worth the time that Tomatis has spent on it. It is striking, however, that if you take away the conclusive chronology, two thousand notes, and the index, of the remaining 600 pages approximately 550 cover the time from the 19 th century to the early 1980s, while only 50 pages deal with the time frame that goes from the mid-1980s to the present time. Yet the 1990s where musically as rich as the 1980s, and the new millennium has brought seismic changes in popular music all over the world, Italy included. It would take a second volume to run through the decades that Tomatis has so compressed. Perhaps it will not need 550 pages, but it will be a different book - not a cultural history but a media history of the Italian song.

By the mid-1980s, the aesthetic, political, and social debate about music was dead. The music was still there and was often as good as it had been before, but what mattered was how to make it visible in the new media landscape of MTV, independent radio, independent TV stations, new TV networks, clubs and - most of all - how to make quick money with it. In an imaginary second volume of Tomatis' cultural history, those endless quotes from intellectuals, journalists, critics, and political activists would be replaced by charts, corporate 
briefings, minutes of business meetings, and marketing strategies. To be sure, music and politics were still connected. It could not be otherwise in a country where a media tycoon became Prime Minister in 1994 and those who were still reeling from the collapse of their faded utopias felt that they were living in another country. (From an interview with Patrizio Fariselli, keyboardist of the progressive group Area, not quoted in Tomatis' book: "All of a sudden, everybody was working for Berlusconi, and if they did not work for Berlusconi... they worked for Berlusconi.")

With the benefit of hindsight, we can therefore evaluate the strength and perhaps the inevitable weakness of Tomatis' approach. The strength, because no other history of Italian song goes that deep in uncovering the cultural relevance of popular music in those strange years. And the weakness, because Tomatis has written the history of the debate about music, in which music was a sideshow. And, more than that, he has no room to spare for the songs that were just pop songs, had no intellectual pretense, and yet became part of the national sentiment and now make the occasional YouTube listeners despair over their lost youth. How many of those songs were, and still are, the guilty pleasure of the connoisseurs? Surrounded as we are by the flat landscape of popular culture, are we sure that those "silly love songs," to quote Sir Paul, mattered less than, say, a modest singer-songwriter who had read a few books and proudly carried his 'message' around?

If Tomatis wants to tell the whole story, he needs to write a third book. Unless he has better things on his mind, I have no doubts that he would be up to the task, especially if I think of the intriguing chapter on the 883 pop group that he wrote for a collective book I edited a few years ago (La memoria delle canzoni. Popular Music e identità italiana, Edizioni puntoacapo, 2016). The purpose of such a desperate enterprise, however, would not be the creation of a hyper-populist canon, but to explore the blessed stupidity of popular music on its own terms - the same beloved stupidity of which we may lose track if we push our cultural paradigms to the limit.

There is a revealing contradiction in the first chapters of Tomatis' book. He gives ample proof that the Italian intellectuals of the 1950s and 1960s where snobbish and disdainful of anything popular. They utterly despised the early 1950s songs associated with the Sanremo Song Festival, which were regressive, consolatory, reactionary, and outright stupid. Who could deny that Italy deserved better than "Papaveri e papere" ("Poppies and Ducks") and "Piripicchio e Piripicchia"? (Both songs could be paired to the 'novelty songs' such as "Mama Will Bark", which in the same years were popular on the other side of the Atlantic.) Yet, while Tomatis scolds the intellectuals for their aloofness, he cannot but agree that those songs were stupid indeed. It took Modugno, the new generation of songwriters, the Milanese cabaret songs, and the relatively unknown but influential Cantacronache group to change the landscape of the Italian song. This is the strong, accepted canon, and nothing can change it.

Or can it? Can music, popular or not, be entirely cleansed of its quantum of stupidity? There may be genius in stupidity too. After all, "Papaveri e papere" is truly an absurdist masterpiece; it would make a Dadaist proud, and there is more inventiveness in it than in 
many boring cantautore songs. In fact, there is plenty of blessed stupidity in every avenue of music, from the childish sublime (Die Zauberflöte: "Pa...pa...pa...pa...") to the grandly ridiculous (Die Walküre: "Hojotoho!"). In Milan Kundera's The Book of Laughter and Forgetting (1979), the narrator's ailing father is taking a walk with his son: "He made a great effort to concentrate, to express what he was thinking, and then, slowly and with difficulty, he said: 'The stupidity of music'." The narrator explains that there is a primeval state of music, a music without thought that mirrors the intrinsic stupidity of the human beings. The narrator has no doubts that the "splendid arc" of Euroclassical music was able to rise above that essential stupidity; yet that great music is perishable while on the contrary "the idiocy of guitars is eternal".

No, not even the idiocy of guitars is eternal; it has been replaced by the idiocy of autotune. Nothing is eternal except genius and stupidity, and they go hand in hand more often than we think. My impression after reliving my twenties through the 550 pages of the 'debate about music' in Tomatis' book was that back then we were taking ourselves too seriously (I took myself too seriously, no question about it). But that would not be a problem today, it's all water under the bridge. The problem is that we may take ourselves too seriously now. The supercilious intellectual attitude of sixty years ago has gone through a complete reversal. Today, the popular music scholar cannot afford not to like the latest fad. That would not be the 'correct' and academically humble approach to the new 'phenomenon', and I don't know if that is a good thing.

In the final chapter of his book, Tomatis addresses, albeit briefly, the new Italian rappers who have rejected the political, folk-music influenced, reggae-and-dub influenced, antagonist rap of the 1990s and have morphed into trappers (trap house rap or, according to a different reading, just trash rap). They have no overt political message; they sing only of themselves, their everyday life (sexism, drugs, and nihilism), their neighborhood, and their ferocious desire for success.

Popular culture changes through coups d'état and new organisms that spread like viruses. Harmonious progress is not what defines it. No one in the 1960s was expecting the rise of the singer-songwriters; no one at the end of the 1970s was predicting the abrupt collapse of the political song (concurrently with the unforeseeable rise and fall of punk on the international scene). The only rule in art is that there is no going back. No one was prepared for trap taking over virtually everything else (Sfera Ebbasta, born Gionata Boschetti in 1992, is the only Italian name in the top-100 Spotify list). Trap is indeed the most impressive, successful, and homegrown trend in the Italian popular music of the last thirty years, much more so than the languid indie-rock scene - and I think that Tomatis, who is a serious scholar and a serious indie-rock musician, will agree on that.

I hope that Tomatis will soon expand his analysis of trap. He points out that Ghali (Ghali Amdouni, born in 1993) has enjoyed positive reviews in pseudo-intellectual circles (TV talking heads, talk shows hosts, etc.) because he is 'decent', not low-class and vulgar like other trappers, more refined, and therefore closer to the reassuring figure of the cantautore that the older generation still cherishes. Which is true, undoubtedly, but it poses a question. 
As a part-time scholar of popular music, and, most of all, as a listener, am I allowed to say that I like Ghali (I do) and Sfera Ebbasta leaves me indifferent without being labeled an elitist? To make myself more understandable to the readers who are not familiar with the recent Italian developments: Am I allowed to say that I prefer Alicia Keys to Beyoncé without some guardian of correctness telling me that I have obviously fallen for the stereotype of the nice girl who is classically trained and can play the piano?

We like good music because it's good and we like bad music, when we like it, because it's bad, even stupid, and not because some 'debate about music' or some academic discipline can turn it into what is not. I live in Texas; allow me therefore a cowboy expression: Tomatis' cultural history has squeezed the cow dry. There is nothing more to say about that old 'debate about music'; he has said it all. From now on, let's focus on the music. And, sometimes, let's have the same fun of the social media listener who likes and dislikes on a whim.

\section{Alessandro CARRERA (Houston)}

